\title{
Anne-Maria Makhulu
}

\author{
A Brief History of the Social Wage: \\ Welfare before and after Racial Fordism
}

Previously, a majority of South Africans were denied welfare in the sense of state provided public or social assistance. Such benefits were largely the preserve of a white minority; black South Africans, by contrast, were forced to develop a variety of strategies for delivering "aided self-help" including the construction of informal housing, the extension of lay care to the elderly and dying, and other modes of associational life that sustained families and communities in the absence of state provided social goods. In addition, the absence of taxes on industry (until the early I950s) and the fact of artificially low wages determined that black South Africans routinely subsidized the social wage.

This essay explores the legacy of racially allocated welfare in South Africa, focusing on the history of the migrant labor system in the context of the discovery of precious metals and minerals in the nineteenth century and the industrial revolution that followed. It outlines a relationship between racial capitalism and precarity-the consequence of the denial of welfare-showing the ways in which the political transition to democracy and the promises of universal welfare were ultimately displaced with the advent of a postFordist regime after I994. 


\section{Apartheid South Africa: A Brief History of Racial Fordism}

Silvia Federici (2004) has written about the emergence of market capitalism in Europe during the early modern period. Tracing the relationship between transformations in gender roles and primitive accumulation, Federici attends not only to what happens in the marketplace but also to the market's effect on the ostensibly "private" domestic domain. She is equally focused on the ways in which, starting in the sixteenth century, the state devised ways of controlling labor through the extension of welfare. Yet, even as early as the fourteenth century, she notes, the "generalization of the anti-feudal struggle" (Federici 2004: 84) had already facilitated new forms of regulationboth fixing the maximum wage and delivering public assistance-that would ultimately drive a decisive wedge between the demands of the manor and the demands of workers. Welfare, in its early expression, was deployed less in order to sustain than to manage a nascent laboring class.

[T] he introduction of public assistance was a turning point in the state relation between workers and capital and the definition of the function of the state. It was the first recognition of the unsustainability of a capitalist system ruling exclusively by means of hunger and terror. (Federici 2004: 84)

By the end of the sixteenth century, a number of European states had developed the capacity to calculate death and poverty rates, the nutritional requirements of both children and adults, and a variety of other metrics as "the first elements of a population policy" (86). In England, for example, public welfare became conditional on forms of social discipline including workhouse confinement, stressing the very strong relationship between poverty, work, and criminalization as a very particular mode of governmentality (85).

In contrast to Federici's account of early modern Europe, in South Africa, through the late nineteenth and early twentieth centuries, "hunger and terror" persisted in energizing racial capitalism. The advent of apartheid in I948 did little to change a general reliance on extreme forms of exploitation as the basis of industrial profit (Makhulu 2012, 20I5, forthcoming). And inasmuch as this was the case, the centerpiece of the racial political economy, namely, the system of migrant wage labor, distinguished between sites of production and reproduction by consigning women to the countryside, poignantly echoing Federici's claims about the intimate relationship between gender status and primitive accumulation.

The legacy of the old system is substantial and South Africans who now face the most uncertain futures-given high levels of unemployment 
after apartheid-express strong feelings of nostalgia for the era of migrant wage work, or what the Left referred to at the time as "racial Fordism" (Gelb I987). This is despite the fact that the migrant labor system disrupted black family life, leaving the domestic domain necessarily both dependent on and subordinate to the itinerancy of men (see, e.g., Hunter 20Io). Women, left to their own devices in the labor reserves (later, the Bantustans), in turn underwrote a more or less nonexistent social wage—raising children, caring for the elderly and infirm, and, in due course, nursing aging and ailing migrant workers including those who returned from South Africa's mines with black lung, silicosis, and tuberculosis. As Bond and McInnes (2007) put it, "capitalists were let off the hook" insofar as the costs of the reproduction of the labor force-including the socialization of children, care of the sick, the aged, and the dying — was systematically borne by women in rural South Africa. For as long as black bodies remained robust and productive, however, their welfare was a key concern of mining and other industrialists who oversaw the minute management of diet and health, housing, and other paternalistic forms of care (see Rajak this issue; Donham 20II).

Hylton White (200I: 459) has described the separation of domains of work and domesticity as an "ideology of dualism" through which African workers were excluded "from the centers of wealth where they labored." This exclusion was primarily achieved by limiting the possible location of black reproduction (pure labor power) outside the city, outside the cosmopolitan space of the urban, in parochial, ethnicized enclaves or "homelands." One way to achieve this was to criminalize the presence of African women in cities. And, as I have already argued, this separation of distinct "private" and "public" spheres necessarily depended on gender superexploitation, creating conditions at once unsustainable and yet self-perpetuating. If Fordism in the northern industrial centers stood for the mass production and consumption of goods coupled to higher wages and higher productivity (White 2012 and Gramsci 197I), such a characterization cannot be said to describe apartheid. South Africa "was a colonial society where profit came from coercive exploitation of cheap, unskilled labor" (White 20I2: 399-400; see also Mamdani I996; Cooper 1983).

In the I960s, neo-Marxists debated the nature of apartheid racial capitalism - the result of "an ongoing history of extremely biased accumulation, combining capitalism and non-capitalist sites of work, of life and of nature" (see Bond 20IO). Acknowledging, at the outset, the state's plainly racist methods of dispossessing blacks of land and livelihood in order to proletarianize an otherwise relatively affluent peasantry (Comaroff and Comaroff 
I99I), a theoretical problem remained: how to explain the persistence of racism (not altogether distinct from Federici's concept of "hunger and terror") and the role racial tyranny played in advancing the interests of a capitalist class. In this sense, class, and race, and gender had to be seen as interrelated domains of domination. Ultimately, it was left to the great Harold Wolpe to note the remarkable collaboration between racial and class projects and to stress that the racial violence of apartheid was necessarily, in itself, motivated by the need to reproduce a specific mode of production. Wolpe (1972: $429)$ would go on to argue that it in no way detracted

from the conception of the State as an instrument of White domination, however, to insist that the South African state is also an instrument of class rule in a specific form of capitalist society.... Viewed from this standpoint racist ideology and policy and the State not only appear as the means for the reproduction of segregation and racial discrimination generally, but also as what they really are, the means for the reproduction of a particular mode of production.

If this particular mode of production depended on racism, it also depended on a biopolitical state to proffer and then at times withhold welfare. We know from Foucault's public lectures of 1978 and 1979 concerning the rise of European biopolitics beginning in the eighteenth century that "biopolitics" represents an effort on the part of governments to rationalize those problems associated with "living beings forming a population" including "health, hygiene, birthrate, life expectancy, race ... " (Foucault 2008: 3I7). To that end, the apartheid state put to work its own biopolitical functions, particularly with regard to the management of populations moving between town and country, and between spheres of production and reproduction (cf. Meillassoux I98I). Just as in Europe during the early modern period, under apartheid, both reproduction and population growth would become matters for the state to decide, albeit in the terms of racial distinction.

I am motivated to rehearse this now well-known South African script because it informs the post-apartheid present-its dilemmas and contradictions - and the great many efforts of scholars, cultural critics, and others in explaining the rising disillusionment with the period after I994. South Africa can be characterized not only by its recent democratization but also by its turn from Fordism to post-Fordism: the shrinking of the industrial sector, the offshoring of manufacturing jobs, the consolidation of land holdings in the hands of a few large agribusiness concerns, and the concomitant mechanization of most farm production, all leading to mass job shedding. Indeed, after 1994 joblessness skyrocketed, and even today the unemploy- 
ment rate is 26.4 percent (the highest rate since about 2003; Statistics South Africa 2015: xiii). In describing contemporary South Africa and a growing discontent expressed primarily in a new "politics of oppositionality" Grant Farred (2004: 592) argues that the problem of South Africa's present is an anti-teleological one. Which is to say that the "propensity ... to think postapartheid South Africa as the disarticulation (and possibly even evacuation of) and triumph over its apartheid predecessor, the narrative of 'progress' from a racist past to a nonracial present (and future)" is countered by the reality of a present that cannot break loose of the "past economic inequities, cultural differences, and racial tensions." Farred (592) submits that "the old illegitimacy [is] replaced by a new, substanceless legitimacy, a formal equality that simply displaces social hierarchy from race into economics; the white/black distinction is transfigured into rich/poor, or "creditor/debtor'" (cf. Seekings and Nattrass 2005; Holston 2008).

The discontinuity with apartheid that many anticipated—a break with history that never fully came to pass-is not simply a historiographical problem; it is also a political one, as Farred suggests. Notably, the politics of oppositionality, what some refer to as the "new social movements" (see, e.g., Desai 2002), has been primarily focused on questions of well-being and human welfare ranging from concerns about adequate housing, education, health care, electrification, access to water, sanitation, and other basic infrastructure. In sum, the new politics has been overwhelmingly invested in making the state meet its responsibility to both rectify the material deprivations of apartheid and to recognize that full or substantive citizenship is always contingent on the satisfaction of the collective welfare.

But here, the anticipated historical sequence is already countered by the realities of the postcolonial present-a present that is continually haunted by a past that cannot be resolved or compensated for. I suggested in the introduction to this issue that the problem of modernity is one of an assumed linear trajectory that colonial histories both comply with and challenge. If South African racial Fordism never really corresponded to Fordism in its "pure" form, it wrested profit from relations of the wage that in turn conformed in no way to the classic Keynesian loop. Then precarity-as the presumed opposite of welfare-has a peculiar standing in this argument. Some would propose that the very notion of precarity presupposes a "relation to the sphere of work, that is, to its decomposition" (Invisible Committee 2009: 44), but what does that imply in a society in which work never guaranteed security despite the current nostalgic investments in a time of work under apartheid. The "anomalous" Keynesianism of apartheid—a Keynesianism 
sans the guaranteed assurances and securities of higher wages and higher productivity-also speaks volumes of the new modes of redundancy after Fordism, that is, in a moment of heightened unemployment, deskilling, and the resort to modes of life beyond the purview of market.

\section{Post-Apartheid South Africa: A Brief History of Post-Fordism}

In the period after 1994, when the South African state started a mass rollout of social grants, pensions, and large-scale development projects like the Reconstruction and Development Programme (RDP), such schemes did remarkably little to alleviate the very deep poverty that persisted across the political transition. Further, for those engaged in formal and even union employment, as in the case of miners working on Lonmin's platinum fields just before the 2012 Marikana massacre, low-wage employment translated in only a limited sense into the relative social advancement that many had assumed would follow. Writing of the particular case of Marikana, Nick Davies (2015) suggests that the new housing, electrification schemes, schools, and public clinics, as well as the significantly expanded system of social assistance though gratifying to a degree (and essential even in households without real income), could in no way counter the lingering effects of an older logic of apartheid capital. The lucky minority that remained in formal employment, despite massive job shedding, lived almost as precariously as those without work (cf. Standing 20II). Before the strike in 20I2, Lonmin miners were earning an average of R4500, or approximately $\$ 450$, per month. Both superexploited and yet responsible for the well-being of countless unemployed dependents, wage work could in no way sustain families, communities, or a majority of South Africans living in poverty (cf. Barchiesi 20II). Describing the legacy of apartheid and the conditions of post-apartheid post-Fordism in which rural kin survive through a combination of social assistance and wage remittances Davies (20I5) observes of a rural town:

The ragged old rondavels which housed the junior school nearby were torn down and replaced with new brick buildings. The government delivered a new asphalt road to the village, a new bus to take children to the high school ... and a new health clinic. And yet, they said, things have not changed so much.

Above all, they said, they still had no real income. Since I994, they had become better off. They have social grants-modest but nonetheless important state funds for pensioners and the sick. And at school there is a feeding 
scheme-porridge at the beginning of the day, a proper meal at lunch. But the reality is that now, as for decades, they still rely on menfolk . . migrating north to work beneath the ground and send home enough to keep them alive. Somewhere along the line, the engine of progress has stalled.

Fanon's “On National Culture” in The Wretched of the Earth ([I963] 2004: I45-80), comprising observations made in the process of witnessing decolonization, concern the difficulties of speaking on behalf of a nearly postcolonial people connected by national identity. While absolutely essential to third world national liberation struggles such claims to national belonging and national identification re-impose, as Fanon sees it, a totalizing conception of the nation or the national space on oppressed peoples who experience both difference and forms of solidarity all the while fighting for political liberation together. This is one of the central paradoxes of national liberation for Fanon (see, e.g., Szeman 2003). It is surely also a paradox of South Africa's political transition-a transition couched less in the terms of decolonization and more so in the euphemistic terms of democratization. Consequently, a majority of poor black and brown South Africans have been forced into perpetuating a struggle for freedom in a moment that Farred and Rita Barnard (2004) describe as a moment "after the thrill is gone" when the actual terms of democratic citizenship have to be worked out.

Consequently, there are renewed efforts at reimagining freedom in the South African postcolony. Such efforts take the form of political movements that are opposed to the broad sweep of post-apartheid reforms favoring the market and the private sector. These include civil society organizations like the Anti-Eviction Campaign (AEC), Anti-Privatization Forum (APF), and South African Homeless People's Federation (SAHPF)—movements focused on access to and rights over land and housing as one remedy to the multiple dispossessions that apartheid wrought and to those that came, not a little ironically, after liberation and with liberalization in 1994 (see,

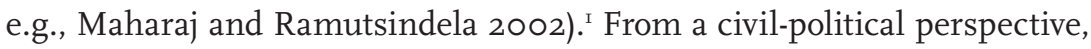
the persistence of segregation (though no longer legally enforceable) calls for repairing both the Manichean and racially fractured arrangement of the urban environment and the stark disparities between the city and the country - the countryside being the place where many poor black South Africans continue to reside. To that end, organizations like Abahlali baseMjondolo $(\mathrm{AbM})^{2}$ - an organization advocating for the homeless and those 
living in informal settlements—has developed a practical,"living politics," which, it argues, serves to humanize the world around it. This is a Fanonian politics in which the forgotten, the marginal, and the disenfranchised are acknowledged, a politics that insists upon a genuinely "democratic" society through housing, land, and other reforms (Gibson 20I2; see also Fanon [I963] 2004; Pithouse 2006). ${ }^{3}$ This is a politics that makes the politics of geography and democracy completely indissociable from one another and in so doing addresses the legacy of the migrant labor system—a system that geographically separated kin, racially ordered space, and starkly divided the towns from the countryside. ${ }^{4}$

Contemporary South Africa is bewildering: a combination of disappointment and dismay. The African National Congress's various promises to eradicate poverty, to nationalize the mines, and to redistribute land (all tenets of the I955 Freedom Charter, a document that in neoliberal times sounds positively anachronistic) have been abandoned. In its place, the post-apartheid state agreed to repay apartheid-era debt, odious debt, which should have been written off. A policy of funding development projects through taxes on the wealthy came to nothing, while South African and transnational corporate capital was exempted from paying any form of financial reparation for the profits they wrought under the old system. The adoption of policies of cost recovery in local government, tight budgetary obligations at the national level, and new free-trade agreements have together made it impossible for future governments to genuinely engage the problems of widespread poverty, unemployment, and the collective welfare. Black Economic Empowerment (BEE) has placed black elites on corporate boards—-keeping white corporate capital "compliant" with the so-called BEE scorecard-rather than investing in schools, clinics, and public housing. These are the kinds of pro-business, prorich, and anti-poor polices that will haunt South Africa for decades (Terreblanche 20I2; see also Marais I999, 20II; Kasrils 20I3).

\section{Conclusion}

Arguably, uneven development and uneven accumulation persist in South Africa (cf. Bond 2013; Fine and Rustomjee 1997; Gelb 1987; Wolpe 1972; Makhulu 20I2) canceling out efforts at reducing inequality. Additionally, neoliberal policies, such as the Growth, Employment, and Redistribution macroeconomic policy (the pro-market framework introduced in I996), have been centrally responsible for sustaining high levels of poverty despite their purported intention to do otherwise. At the same time, the South African 
state's involvement in housing and other forms of supposed welfarism might be construed as a rolling back of pro-market principles. But as David McDonald (2008: 75) has argued, the extension of the South African state's participation, its "strength," is in fact entirely consistent with neoliberalism: on the one hand the focus is "cost recovery and other forms of social and economic discipline," which "remain the primary objectives" of the state. On the other hand, welfare-including housing provision, antiretroviral rollout, and the massive system of social grants (Ferguson 2007, 2013) while marking an increased presence by the state, should be understood in historical perspective. "The most obvious difference," McDonald argues, "is that the welfarism of apartheid was highly skewed along racial (and to some extent ethnic) lines, complicating the moments of neoliberal destruction and creation" (75). Plainly, for the very absence of welfare for a majority of South Africans in the past, the introduction of new welfare policies in the postI994 period is more suggestive of a kind of historical adjustment than an expansion of a large welfare apparatus as such.

By contrast, James Ferguson (2007: 79) argues that the extensive apparatus of social grants (based on disability, parental status, or age eligibility) and the proposed basic income grant, are "both pro-poor and neoliberal" and, hence, ideologically incoherent. Though social grants undeniably sustain households, their capacity for genuine poverty reduction is questionable, not least because economic policy in South Africa has neglected the need for job creation leading to a significant decline in labor's portion of the social surplus. For this reason, social grants can hardly be considered "pro-poor" or poverty alleviating, even if many South Africans have become heavily dependent on them. ${ }^{5}$

For all that, the new social movements continue to insist on a place in the national society and to remind their fellow citizens of "the importance of popular control over communities and movements, and the importance of ... criticism of how elites, in and out of the state, on the right and on the left, habitually fail to accept the agency of those who are, in Fanon's terms, the damned of the earth" (Gibson 20I2: 53; see also Fanon [1963] 2004: I45). Further, "poor people are talking about the government in a sharp, critical way for the first time ... connecting unemployment and electricity blackouts to bad governance," reckoning a relationship between the fact of landlessness, homelessness, and the insatiable bid on the part of capital to privatize everything, and demanding that the state take responsibility for the collective welfare (see Okeowo 20I5). Little wonder that South Africa has become the protest capital of the world! 


\section{Notes}

I Such policies of liberalization include the Growth Employment and Redistribution (GEAR) strategy adopted in 1996 .

2 Previously a Durban based organization; AbM now has members in a number of cities.

3 For Fanon apartheid represented the purest form of colonial spatial politics.

4 Addressing South Africa's shaky developmentalist path since I994 (and the adoption of the Reconstruction and Development Programme) the National Development Plan acknowledges a post-apartheid pattern of locating the poor on the city outskirts, one, and two, the persistence of rural poverty. See National Development Plan: Vision for 2030.

5 In 2005 the total consumer expenditure for the bottom 60 percent of South Africans was slightly less than that of the top 5.7 percent, which totaled over RI72 billion. Further, despite a newly deracialized welfare system, the level of many subsidies fell dramatically between 1994 and I999. Child grants, for example, dropped by 40 percent.

\section{References}

Barchiesi, Franco. 20II. Precarious Liberation: Workers, the State, and Contested Social Citizenship in Postapartheid South Africa. Albany: SUNY Press.

Bond, Patrick. 20I0. "A Half-Century of Competing Political Economic Traditions in South Africa." Paper presented at Race, Class, and the Developmental State conference, Port Elizabeth, November I6.

Bond, Patrick. 20I3. "Debt, Uneven Development and Capitalist Crisis in South Africa: From Moody's Macroeconomic Monitoring to Marikana Microfinance Mashonisas." Third World Quarterly 34, no. 4: 569-92.

Bond, Patrick, and Peter McInnes. 2007. "Decommodifying Electricity in Postapartheid Johannesburg." In Contesting Neoliberalism: Urban Frontiers, edited by Helga Leitner, Jamie Peck, and Eric S. Sheppard, I57-78. New York: The Guilford.

Comaroff, John L., and Jean Comaroff. I99I. Of Revelation and Revolution, Volume One: Christianity, Colonialism, and Consciousness in South Africa. Chicago: University of Chicago Press.

Cooper, Frederick. 1983. Struggle for the City: Migrant Labor, Capital, and the State in Urban Africa. Beverly Hills: Sage.

Davies, Nick. 2015. "Marikana Massacre: The Untold Story of the Strike Leader Who Died for Workers' Rights." Guardian, May 19. www.theguardian.com/world/2015/may/19 /marikana-massacre-untold-story-strike-leader-died-workers-rights?CMP=share_btn_fb.

Desai, Ashwin. 2002. We Are the Poors: Community Struggles in Post-Apartheid South Africa. New York: Monthly Review.

Donham, Donald L. 20II. Violence in a Time of Liberation: Murder and Ethnicity at a South African Gold Mine, 1994, with photographs by Santu Mofokeng. Durham, NC: Duke University Press.

Fanon, Frantz. (1963) 2004. The Wretched of the Earth. New York: Grove Press.

Farred, Grant, and Rita Barnard. 2004. "After the Thrill Is Gone: A Decade of Post-Apartheid South Africa." Special issue of South Atlantic Quarterly 103, no. 4. 
Farred, Grant. 2004. "The Not-Yet Counterpartisan: A New Politics of Oppositionality." South Atlantic Quarterly I03, no. 4: 589-605.

Federici, Silvia. 2004. Caliban and the Witch: Women, the Body and Primitive Accumulation. New York: Autonomedia.

Ferguson, James. 2007. "Formalities of Poverty: Thinking About Social Assistance in Neoliberal South Africa." African Studies Review 50, no. 2: 7I-86.

Ferguson, James. 2013. "Declarations of Dependence: Labour, Personhood, and Welfare in Southern Africa." Journal of the Royal Anthropological Institute 19: 223-42.

Fine, Ben, and Zavareh Rustomjee. 1997. South Africa's Political Economy: From MineralsEnergy Complex to Industrialisation. London: Hurst and Company.

Foucault, Michel. 2008. The Birth of Biopolitics: Lectures at the Collège de France, 1978-1979. New York: Palgrave Macmillan.

Gelb, Steve. 1987. "Making Sense of the Crisis." Transformation 5: 33-50.

Gibson, Nigel. 20I2. "What Happened to the 'Promised Land'? A Fanonian Perspective on Post-Apartheid South Africa." Antipode 44, no. I: 5I-73.

Gramsci, Antonio. 197I. Selections from the Prison Notebooks of Antonio Gramsci. Edited by Quintin Hoare and Geoffrey Nowell Smith. New York: International.

Holston, James. 2008. Insurgent Citizenship: Disjunctions of Democracy and Modernity in Brazil. Princeton, NJ: Princeton University Press.

Hunter, Mark. 20Iо. Love in the Time of AIDS: Inequality, Gender, and Rights in South Africa. Bloomington: Indiana University Press.

Invisible Committee. 2009. The Coming Insurrection. Cambridge, MA: Semiotext(e).

Kasrils, Ronnie. 20I3. "How the ANC's Faustian Pact Sold Out South Africa's Poorest." Guardian, June 24. www.theguardian.com/commentisfree/2013/jun/24/anc-faustian-pact -mandela-fatal-error.

Maharaj, Brij, and Maano Ramutsindela. 2002. "Introduction: Post-Apartheid Political Dispensation-New or Old Geographies?” GeoJournal 57: I-2.

Makhulu, Anne-Maria. 20I2. "The Conditions for After Work: Financialization and Informalization in Posttransition South Africa," Publication of the Modern Language Association I27, no. 4: 782-99.

Makhulu, Anne-Maria. 20I5. Making Freedom: Apartheid, Squatter Politics, and the Struggle for Home. Durham, NC: Duke University Press.

Makhulu, Anne-Maria. Forthcoming. "The Debt Imperium: Relations of Owing after Apartheid." In Beyond the Margins: The Political Economy of Life in Modern Africa (essays in honor of Jane I. Guyer), edited by Wale Adebanwi. Bloomington: Indiana University Press.

Mamdani, Mahmood. 1996. Citizen and Subject: Contemporary Africa and the Legacy of Late Colonialism. Princeton, NJ: Princeton University Press.

Marais, Hein. I999. South Africa, Limits to Change: The Political Economy of Transition. New York: Zed Books.

Marais, Hein. 20II. South Africa Pushed to the Limit: The Political Economy of Change. New York: Palgrave.

McDonald, David A. 2008. World City Syndrome: Neoliberalism and Inequality in Cape Town. New York: Routledge.

Meillassoux, Claude. I98I. Maidens, Meal, and Money: Capitalism and the Domestic Community. New York: Cambridge University Press. 
124 The South Atlantic Quarterly · January 2016

Okeowo, Alexis. 2015. "Can Thulisile Madonsela Save South Africa From Itself?” New York Times, June I6. www.nytimes.com/2015/06/21/magazine/can-thulisile-madonsela -save-south-africa-from-itself.html?_r=0.

Pithouse, Richard. 2006. "Struggle Is a School: The Rise of a Shack Dweller's Movement in Durban, South Africa." Monthly Review 57, no. 9: 30-5I.

Seekings, Jeremy, and Nicoli Nattrass. 2005. Class, Race, and Inequality in South Africa. New Haven, CT: Yale University Press.

Standing, Guy. 20II. The Precariat: The New Dangerous Class. London: Bloomsbury Academic.

Statistics South Africa. 20I5. "Quarterly Labour Force Survey: Quarter I." statssa.gov.za, May 26. www.statssa.gov.za/publications/Po2II/Po2IIIstQuarter20I5.pdf.

Szeman, Imre. 2003. Zones of Instability: Literature, Postcolonialism, and the Nation. Baltimore: Johns Hopkins University Press.

Terreblanche, Sampie. 2012. Lost in Transformation: South Africa's Search for a New Future since 1986. Johannesburg: KMM Review.

White, Hylton. 200I. "Tempora et Mores: Family Values and the Possessions of a Post-Apartheid Countryside." Journal of Religion in Africa 31, no. 4: 457-79.

White, Hylton. 20I2. "A Post-Fordist Ethnicity: Insecurity, Authority, and Identity in South Africa." Anthropological Quarterly 85, no. 2: 397-428.

Wolpe, Harold. 1972. "Capitalism and Cheap Labour-Power in South Africa: From Segregation to Apartheid." Economy and Society I, no. 4: 425-56. 